\title{
Porang Glucomannan Supplementation Improves Lipid Profile in Metabolic Syndrome Induced Rats
}

\author{
Azizah Hikma Safitri ${ }^{1 *}$, Nurina Tyagita ${ }^{1}$ and Taufiqurrachman Nasihun ${ }^{2}$ \\ ${ }^{1}$ Department of Biochemistry, Medical Faculty of Sultan Agung Islamic University, Semarang, Indonesia; \\ azizah.safitri@unissula.ac.id \\ ${ }^{2}$ Department of Biochemistry and Master Program of Biomedical Sciences of Sultan Agung Islamic University, \\ Semarang, Indonesia
}

\begin{abstract}
Background: Porang glucomanan has been shown to have a potential properties for the prevention of Metabolic Syndrome (MetS). This study aimed to investigate that porang glucomannan supplementation can improve lipid profile in metabolic syndrome induced rats. Methods: Thirty male Sprague-Dawley rats were randomly divided into 5 groups consisting a contol group standard diet (Normal); metabolic syndrome group (SM), metabolic syndrome group $+25 \mathrm{mg} / 200 \mathrm{gBW}$ porang glucomannan (GMP25), metabolic syndrome group + 50mg/200gBW porang glucomannan (GMP50), and metabolic syndrome group $+100 \mathrm{mg} / 200 \mathrm{gBW}$ porang glucomannan (GMP100). The lipid profile before and after induction with high-fat and high-carbohydrate diet, and after 28 days of porang glucomannan supplementation were evaluated. Data were analyzed using One Way Anova followed by LSD Post Hoc test. Results: GMP100 group showed the highest reversal of diet-induced changes, with decreased total cholesterol (TC), triglycerides (TG), and LDL, and also increased HDL level. The mean levels of TC, TG, and LDL in GMP100, GMP50 and GMP25 was significantly lower than those of in SM $(p=0.000)$, and was significantly higher than those of normal $(p=0.000)$. While the levels of HDL in GMP 100, GMP50, and GMP25 was significantly higher than those of SM $(p=0.000)$, but significantly lower than those of normal ( $p$ $=0.000$ ). Conclusion: Porang glucomannan supplementation improves lipid profile in metabolic syndrome induced rats with best dose at $100 \mathrm{mg} / 200 \mathrm{gBW}$.
\end{abstract}

Keywords: Glucomannan, Lipid Profile, Metabolic Syndrome, Porang

\section{Introduction}

Excessive calorie intake and lack of physical activity of sedentary lifestyle has been health problem in modern societies. Such lifestyle can trigger diseases such as type 2 diabetes mellitus and Cardiovascular Diseases (CVDs). Complex risk factors for Cardiovascular Diseases (CVDs) and diabetes mellitus type 2 are interrelated and often occur simultaneously known as Metabolic Syndrome (MetS) ${ }^{1}$. MetS has been a major health problem worldwide. It is estimated that $20-25 \%$ of the world's adult population have MetS ${ }^{2}$. In 2015, American Heart Association reported that the prevalence of MetS continues to increase globally ${ }^{3}$. Overall prevalence of MetS in the United States from the years 2003-2012 was estimated at 33\%, with the higher prevalence in women than men $(35.6 \%$ vs.

*Author for correspondence 
$30.3 \%, \mathrm{p}<0.01)^{4}$. In Africa, the overall prevalence of the MetS is estimated at between $17-25 \%{ }^{5}$. Similiarly, MetS prevalence according to the WHO definition of the MetS in seven European countries is estimated at $23 \%{ }^{6}$. In several East and Southeast Asian countries, the prevalence of MetS is estimated to be $10-30 \%{ }^{7}$. The global high prevalence of MetS world have shifted the leading cause of death in the $21^{\text {st }}$ century.

Various definitions related to MetS and the criteria for diagnosis of MetS has been established by several expert group. According to the NCEPATP III criteria, MetS is diagnosed when a patient has at least 3 of the following 5 conditions: waist circumference over $102 \mathrm{~cm}$ (men) or $88 \mathrm{~cm}$ (women), hypertriglyceridemia (triglyceride serum $>150 \mathrm{mg} /$ $\mathrm{dL}), \mathrm{HDL}-\mathrm{C}<40 \mathrm{mg} / \mathrm{dL}$ for $\mathrm{men}$, and $<50 \mathrm{mg} / \mathrm{dL}$ for women; blood pressure >130/85 mmHg; and fasting blood glucose levels $>110 \mathrm{mg} / \mathrm{dL}$. In its application, MetS with NCEP-ATP III diagnostic criteria specific to waist normal value was adjusted to suit Asian ethnicity body size ( $\geq 90 \mathrm{~cm}$ in men and women $\geq 80$ $\mathrm{cm})$, as a limitation of central obesity ${ }^{2}$.

Lipid profile is one of the reliable MetS parameters. Previous studies have shown an association between lipid profile and MetS related variables $^{8}$. Another study using multiple linear regression analysis of the ratio of TG/HDL-C, TC/HDL-C and TG showed a strong significant relationship among the three variables of the MetS in both men and women in the adult population in Japan $^{9}$. Lipid metabolism and insulin resistance play a major role in the pathogenesis of the Met $S^{10}$. These studies showed that improvements in lipid profile are one of the key factor in controlling the MetS. International Diabetes Federation recommended the primary management of the MetS relying on controllable lifestyle including dietary intake ${ }^{2}$. Sufficient fiber consumption has been shown to reduce body weight, dyslipidemia, hypertension and improve insulin sensitivity leading to decrease the prevalence of the MetS ${ }^{11}$.

Glucomannan is soluble fiber from Amorphophallus konjac. In some Asian countries glucomannan used as food, traditional medicine, and weight loss supplement. Epidemiological and clinical studies stated that dietary supplementation with glucomannan at certain dose has been shown have many benefits including: weight loss in obesity and overweight, increases HDL levels both in children and adults, reduce levels of LDL, and reduce the risk of cancer and cardiovascular disease $^{12}$. Glucomannan also potential as a source of monooligosaccharide prebiotics due to its modulating effect to the microflora in the gastrointestinal tract ${ }^{13}$. Glucomannan mechanism of the modulating effect has been shown to be similiar with other soluble fibers i.e., fermentable fiber. Fermented glucomannan in the colon will lead to the formation of propionic acid capable of decreasing the synthesis of cholesterol ${ }^{12}$. Propionate, as a member of short chain fatty acid class, has ability to inhibit cholesterol synthesis. Some literature clearly stated that the glucomannan can lower cholesterol by interfering cholesterol absorbtion mediated by the viscosity and increasing the fecal excretion of bile acids ${ }^{14}$. High viscosity of 
glucomannan limits the enterohepatic circulation of bile acids and cholesterol ${ }^{15}$.

The Porang (Amorphophallus muelleri Blume), an indigenous Indonesian plant, has not been explored optimally for food and the solution of health problems. Previous studies showed that porang contains a high dietary fiber in the form of glucomannan around 55\% (dry basis) ${ }^{16}$. Despite the fact that glucommanan from Amorphophallus muelleri Blume is almost the same as that of from Amorphophallus Konjac which have been produced in commercial supplement form, there have been few studies on the potential of glucomannan from porang for disease prevention and treatment including metabolic syndrome.

The aim of this study was to investigate that porang glucomannan supplementation can improve lipid profile of experimental animal model of MetS. The results of this study are expected to be used as a reference for the treatment of MetS, especially in improving lipid profiles playing a major role in the pathogenesis of MetS.

\section{Material and Methods}

In experimental study with pre and post test control group design, a total of thirty male Sprague-Dawley rats ( \pm 8 weeks old and $\pm 150-200$ g body weigh), obtained and maintained in Centre for Food and Nutrition of Gajah Mada University, YogyakartaIndonesia (Pusat Studi pangan dan Gizi Universitas Gajah Mada, Yogyakarta-Indonesia). A total of 30 rats were divided into 5 groups of 6 rat each: normal group (Normal), metabolic syndrome group (SM), metabolic syndrome group $+25 \mathrm{mg} / 200 \mathrm{gBW}$ porang glucomannan (GMP25), metabolic syndrome group + 50mg/200gBW porang glucomannan (GMP50), and metabolic syndrome group + $100 \mathrm{mg} / 200 \mathrm{gBW}$ porang glucomannan (GMP100). Before the metabolic syndrome induction, all rats were acclimatized for 7 days. The 6 rats in normal group were fed only with a standard diet (AIN-93M pellet). While a total of 24 metabolic syndrome rats (SM group), GMP25, GMP50, and GMP 100 were fed with a standard diet (AIN-93M pellet) + high-fat and high-carbohydrate diet using quail egg yolk and high-dosage of fructose as an inducer for metabolic syndrome for 21 days. The administration of diet performed ad libitum. After 21 days induction of metabolic syndrome, rats in GMP25, GMP50 and GMP100 group were supplemented with porang glucomannan at the dose of $25 ; 50 ; 100 \mathrm{mg} / 200 \mathrm{gBW}$ for the following 28 days. porang glucomannan with cold aquades solvent was orally administrated with the help of feeding tube. The approval of this study procedure was obtained from the Research Bioethics Committee of the Faculty of Medicine, Sultan Agung Islamic University Semarang, Central Java, Indonesia (No. 290/IX/2017/Bioethics Commission).

\subsection{Preparation of Porang Glucomannan}

The porang glucomannan used in this study was purchased from CV. Nura Jaya Surabaya, Indonesia. The glucomannan was made from indiginous Indonesian Porang of species of Amorphophallus muelleri Blume. The concentration of the glucomannan from porang used in this study was $66.43 \%$ as shown in Table 1 . The analysis of porang flour was conducted at The Laboratory of 
Table 1: Analysis of porang flour composition

\begin{tabular}{|c|c|c|}
\hline Component & Testing Method & Composition \\
\hline Water & Gravimetry & $8.88 \%$ \\
\hline Ash & Gravimetry & $3.28 \%$ \\
\hline Fat level & Soxhlet & $1.01 \%$ \\
\hline Protein level & Kjeldahl & $1.25 \%$ \\
\hline Carbohydrate & By Different & $85.58 \%$ \\
\hline Starch & Spectrophotometry & $67.45 \%$ \\
\hline Glucomannan & Gravimetry & $66.43 \%$ \\
\hline Oxalic acid & HPLC & $133.07 \mathrm{ppm}$ \\
\hline
\end{tabular}

Testing Center for Research Development of PostHarvest Agriculture (Laboratorium Pengujian Balai Besar Penelitian dan Pengembangan Pascapanen Pertanian).

\subsection{The Evaluation of Metabolic Syndrome Parameters}

The MetS parameters were evaluated at four different time. Blood serum was collected on day 1 (after 7 days acclimatization), day 22 (after induction of MetS), day 36 (14 days after porang glucomannan supplementation) and day 49 (28 days after porang glucomannan supplementation). Blood serums were subjected to the assessment of lipid profile including Total Cholesterol (TC), Triglyceride (TG), Low-Density Lipoprotein (LDL) cholesterol, High-Density Lipoprotein (HDL) cholesterol.
Total cholesterol level was measured by enzymatic photometric test using CHOD-PAP, triglyceride with colorimetric enzymatic test using Glycerol3-Phosphate-Oxidase (GPO-PAP), LDL and HDL with the CHOD-PAP method on photometric systems.

\subsection{Data Analysis}

Data were expressed as mean and standard deviation. Prior to the multivariate test, normality and homogeneity tests were performed. One-way Analysis of Variance (ANOVA) followed by LSD Post Hoc test was used to compare data among groups. The statistical test was performed at a 95\% confidence Interval, and the difference was considered significant when the $p$ value $<0.05$. 
Table 2: Mean and $\Delta( \pm S D)$ of TC, TG, LDL, and HDL cholesterol levels between SM group and GMP groups after induction (D-22) with high-fat and high-carbohydrate diet for 21 days and 28 days after porang glucomannan supplementation (D-49)

\begin{tabular}{|c|c|c|c|c|c|c|c|c|c|c|c|c|}
\hline \multirow{3}{*}{ Groups } & \multicolumn{12}{|c|}{ Variables } \\
\hline & \multicolumn{3}{|c|}{$\mathrm{TC}(\mathrm{mg} / \mathrm{dL})$} & \multicolumn{3}{|c|}{ TG (mg/dL) } & \multicolumn{3}{|c|}{ LDL (mg/dL) } & \multicolumn{3}{|c|}{$\mathrm{HDL}(\mathrm{mg} / \mathrm{dL})$} \\
\hline & D-22 & D-49 & $\Delta$ & D-22 & D-49 & $\Delta$ & D-22 & D-49 & $\Delta$ & D-22 & D-49 & $\Delta$ \\
\hline Normal & $\begin{array}{c}80.65 \\
\pm 1.8\end{array}$ & $\begin{array}{l}81.63 \\
\pm 2.9\end{array}$ & $\begin{array}{c}1.04 \\
\pm 0.75\end{array}$ & $\begin{array}{c}70.91 \\
\pm 2.8\end{array}$ & $\begin{array}{c}73.56 \\
\pm 4.0\end{array}$ & $\begin{array}{c}3.06 \\
\pm 1.45\end{array}$ & $\begin{array}{c}24.57 \\
\pm 2.0\end{array}$ & $\begin{array}{l}27.36 \\
\pm 2.4\end{array}$ & $\begin{array}{c}2.29 \\
\pm 0.36\end{array}$ & $\begin{array}{c}69.50 \\
\pm 3.5\end{array}$ & $\begin{array}{l}67.19 \\
\pm 2.0\end{array}$ & $\begin{array}{c}1.70 \\
\pm 1.01\end{array}$ \\
\hline SM & $\begin{array}{c}186.47 \\
\pm 3.7\end{array}$ & $\begin{array}{c}187.47 \\
\pm 3.3\end{array}$ & $\begin{array}{c}1.35 \\
\pm 0.58\end{array}$ & $\begin{array}{c}129.21 \\
\pm 2.7\end{array}$ & $\begin{array}{c}132.46 \\
\pm 2.0\end{array}$ & $\begin{array}{c}3.55 \\
\pm 1.01\end{array}$ & $\begin{array}{c}76.01 \\
\pm 1.2\end{array}$ & $\begin{array}{l}78.6 \\
\pm 1.6\end{array}$ & $\begin{array}{c}2.76 \\
\pm 0.63\end{array}$ & $\begin{array}{c}27.21 \\
\pm 1.8\end{array}$ & $\begin{array}{l}24.58 \\
\pm 1.3\end{array}$ & $\begin{array}{c}2.96 \\
\pm 1.37\end{array}$ \\
\hline GMP25 & $\begin{array}{c}183.89 \\
\pm 3.2\end{array}$ & $\begin{array}{c}138.45 \\
\pm 3.6\end{array}$ & $\begin{array}{r}47.18 \\
\pm 4.44\end{array}$ & $\begin{array}{c}130.39 \\
\pm 2.7\end{array}$ & $\begin{array}{c}118.05 \\
\pm 3.4\end{array}$ & $\begin{array}{r}13.46 \\
\pm 2.05\end{array}$ & $\begin{array}{c}78.43 \\
\pm 1.1\end{array}$ & $\begin{array}{c}44.49 \\
\pm 2.1\end{array}$ & $\begin{array}{l}34.65 \\
\pm 1.46\end{array}$ & $\begin{array}{c}25.85 \\
\pm 3.0\end{array}$ & $\begin{array}{c}46.20 \\
\pm 1.9\end{array}$ & $\begin{array}{r}21.19 \\
\pm 4.19\end{array}$ \\
\hline GMP50 & $\begin{array}{c}184.79 \\
\pm 3.1\end{array}$ & $\begin{array}{c}124.82 \\
\pm 4.1\end{array}$ & $\begin{array}{r}61.46 \\
\pm 3.86\end{array}$ & $\begin{array}{c}128.27 \\
\pm 1.8\end{array}$ & $\begin{array}{c}103.89 \\
\pm 3.4\end{array}$ & $\begin{array}{r}25.44 \\
\pm 3.85\end{array}$ & $\begin{array}{c}77.28 \\
\pm 1.5\end{array}$ & $\begin{array}{l}37.19 \\
\pm 1.7\end{array}$ & $\begin{array}{c}40.67 \\
\pm 1.82\end{array}$ & $\begin{array}{c}24.94 \\
\pm 1.5\end{array}$ & $\begin{array}{c}55.99 \\
\pm 3.0\end{array}$ & $\begin{array}{r}32.03 \\
\pm 2.94\end{array}$ \\
\hline GMP100 & $\begin{array}{c}184.23 \\
\pm 3.4\end{array}$ & $\begin{array}{c}101.34 \\
\pm 3.2\end{array}$ & $\begin{array}{r}83.27 \\
\pm 1.15\end{array}$ & $\begin{array}{c}128.15 \\
\pm 3.0\end{array}$ & $\begin{array}{l}91.23 \\
\pm 3.2\end{array}$ & $\begin{array}{r}37.62 \\
\pm 1.95\end{array}$ & $\begin{array}{c}76.70 \\
\pm 2.4\end{array}$ & $\begin{array}{l}28.15 \\
\pm 2.3\end{array}$ & $\begin{array}{r}49.54 \\
\pm 3.81\end{array}$ & $\begin{array}{c}24.94 \\
\pm 1.8\end{array}$ & $\begin{array}{l}62.67 \\
\pm 2.4\end{array}$ & $\begin{array}{r}38.36 \\
\pm 1.64\end{array}$ \\
\hline $\operatorname{Sig}(p)$ & 0.56 & 0.000 & 0.000 & 0.421 & 0.000 & 0.000 & 0.238 & 0.000 & 0.000 & 0.103 & 0.000 & 0.000 \\
\hline
\end{tabular}

\section{Results}

3.1 The Mean Decrease in TC, TG, LDL and HDL Cholesterol Levels Before and After Porang Glucomannan Supplementation After induction of MetS and before the difference in the levels of TC, TG, LDL and HDL administration of the treatment, measurement were underwent to determine whether the levels of TC, TG, LDL and HDL between the groups were comparable. Measurements also aimed to evaluate the successfullness of induction of MetS. One Way ANOVA test showed that there were no significant 


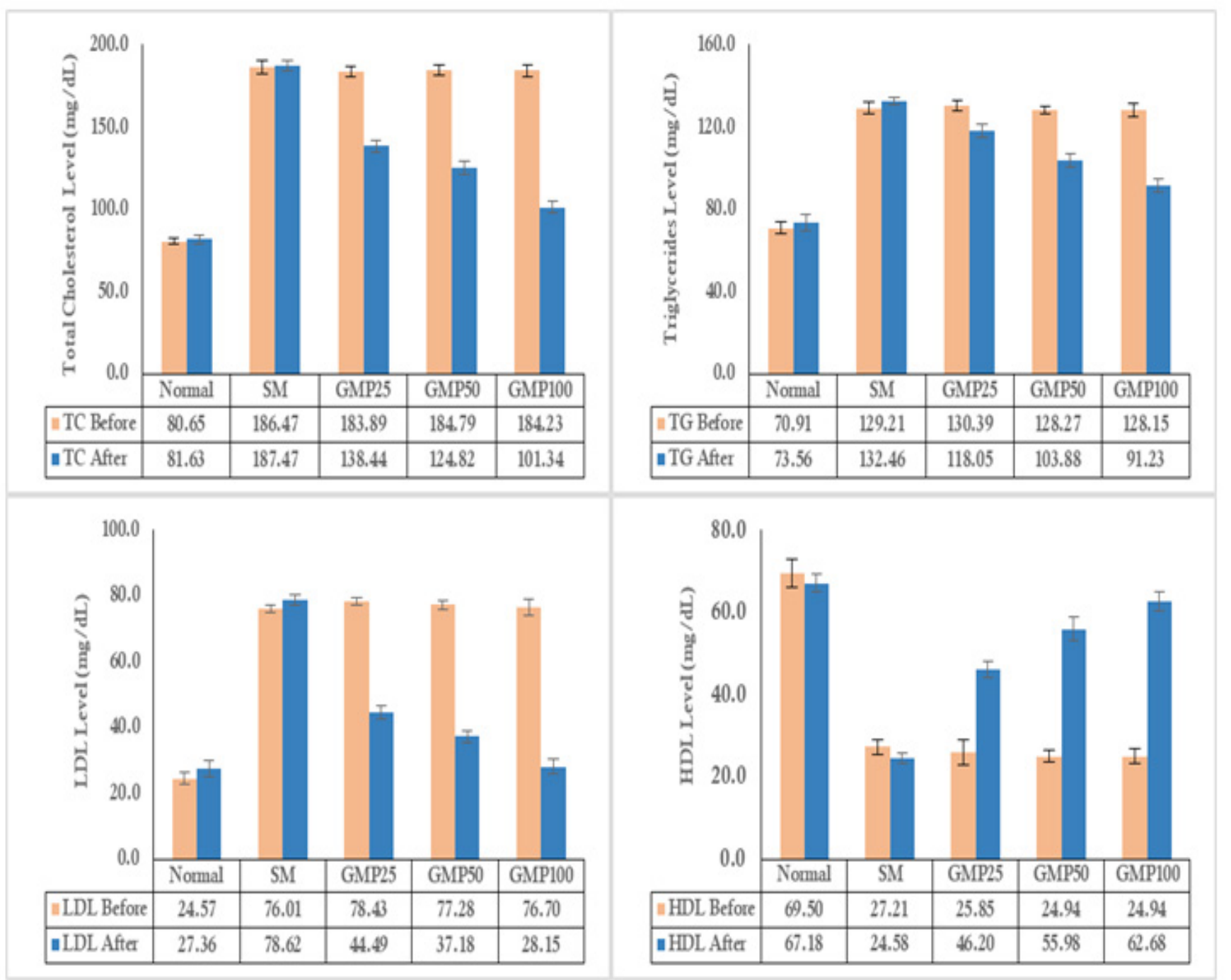

Fig. 1. Total cholesterol (TC), triglycerides (TG), low-density lipoprotein (LDL), and high-density lipoprotein (HDL) (mg/ $\mathrm{dL}$ ) before and after 28 days porang glucomannan supplementation (Mean \pm SD).

( $p>0.05)$ for the SM group and GMP groups in day 22 (after induction of MetS) as shown in Table 2.

The results of this study were interesting, three of 4 variables of the study showed the same average of the decrease in sequence. The highest mean decrease in TC, TG, and LDL level were found in GMP 100, followed by GMP50, GMP 25, and SM group. Normal group had the lowest mean decrease in TC, TG, and LDL level, as in the normal group was not induced with MetS diet. While the highest mean increase in HDL levels was found in GMP 100, followed by GMP50, GMP 25, and SM group (Figure 1). The normal group had the lowest mean decrease in $\mathrm{HDL}$, because normal group was not induced with MetS diet. The mean delta of TC, TG, LDL, and HDL were then analyzed with Kruskall 

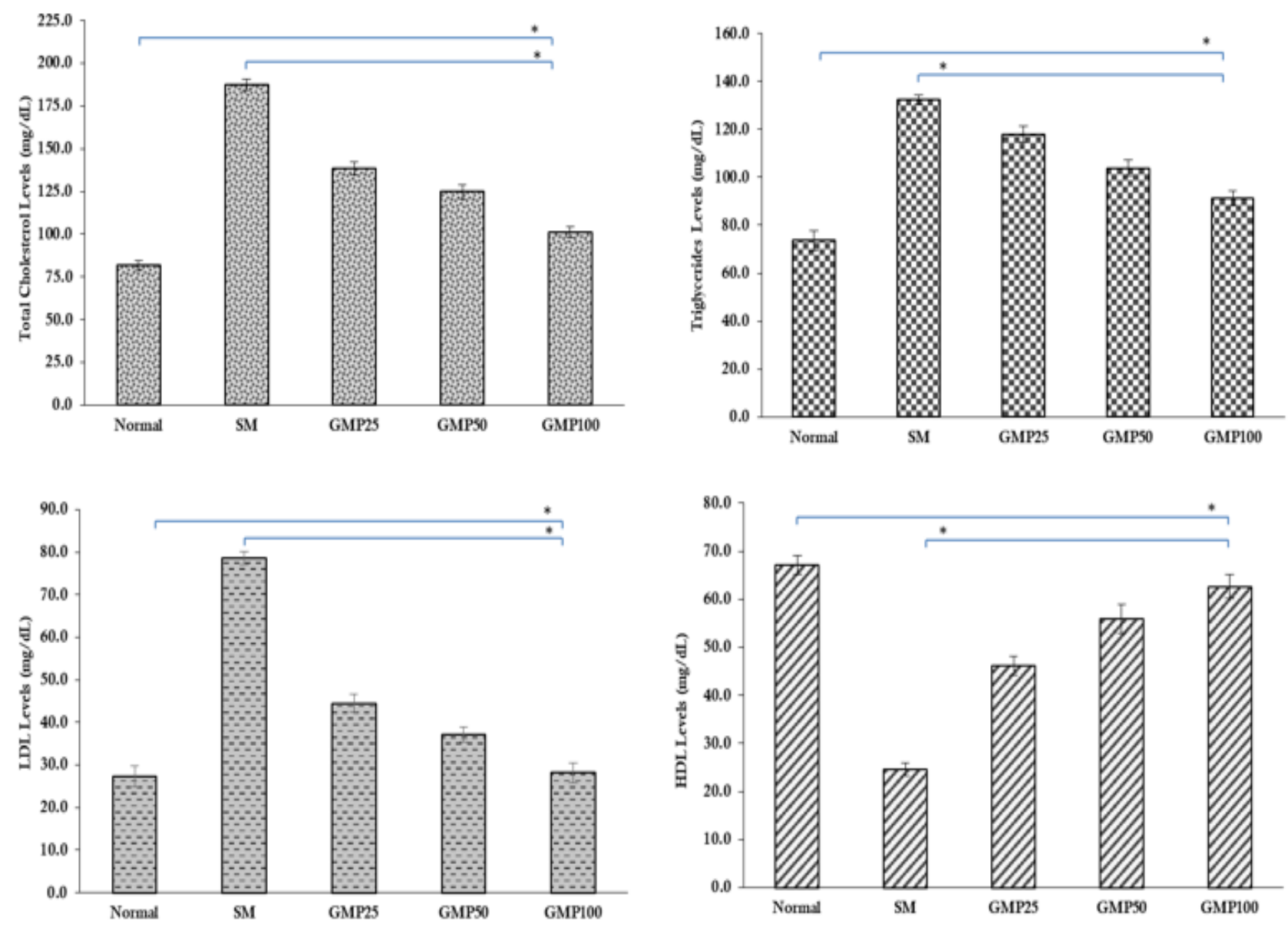

Fig. 2. Total cholesterol (TC), triglycerides (TG), low-density lipoprotein (LDL), and high-density lipoprotein (HDL) (mg/ $\mathrm{dL}$ ) after 28 days porang glucomannan supplementation; The $\Delta$ (differences) of TC, TG, LDL, and HDL among groups. LSD Post-Hoc analysis: ${ }^{*} p<0.05$.

Wallis test, resulting in significant difference between groups on all variables $(p<0.05)$.

\subsection{The Mean Levels of TC, TG, LDL, and HDL After Porang Glucomannan Supplementation}

As shown in Table 2, the differences in four parameters of lipid profile after porang glucomannan supplementation indicates that the metabolic syndrome group had the highest mean of TC level, TG level, LDL level followed by GMP25, GMP50, GMP100 and the normal group. Measurement of these three variables were interesting, because it has the same pattern among groups that have the lowest to highest average level (porang supplementation dose dependently decreased TC, TG, and LDL levels). The highest mean level of HDL was found in normal group, followed by GMP100, GMP50, GMP25 and the metabolic syndrome group. The results of mean TC, TG, LDL, and HDL analyzed by One Way ANOVA for parametric test, and resulted in a significant differences between groups on all variables $(p<0.05)$. 
LSD Post Hoc test results showed that levels of TC, TG, and LDL in the normal group was significantly lower compared with that of the SM group and GMP group $(p=0.00)$. TC, TG, and LDL cholesterol levels in the GMP 100 group were significantly lower than those in the GMP50, GMP25, whereas in the GMP50 group the TC, TG, and LDL cholesterol levels were significantly lower than those in the GMP25 ( $p=0.00)$. In the SM group the TC, TG, and LDL cholesterol levels were significantly higher than the GMP groups and Normal group $(p=0.00)$. Unlike the previous three parameters, the results of LSD Post Hoc test showed that HDL cholesterol levels in the normal group was significantly higher than the SM group and GMP groups. HDL levels in GMP100 group was significantly higher than GMP50 and GMP25 group, while the group GMP50 HDL levels significantly higher than those GMP25. While the HDL level in the SM group significantly lower than normal group, GMP100, GMP50, and GMP25 (Figure 2).

\section{Discussion}

Improved blood lipid profiles correlated with the reduction of parameters associated with MetS due to high total cholesterol, triglyceride, LDL levels and low HDL levels. This study investigated supplementation of porang glucomannan on blood lipid profile in rats with diet induced MetS. This is done in an attempt to prove the benefits of glucomannan contained in Indonesian native porang as one of the MetS therapy, especially in terms of improved food intake. The study showed that supplementation of porang glucomannan at doses of $25 \mathrm{mg}, 50 \mathrm{mg}$, and $100 \mathrm{mg} / 200 \mathrm{gBW}$ significantly decreased TC, TG, LDL, and increased HDL levels at the end of the trial in high-fat and highcarbohydrate diet induced metabolic syndrome.

The results of this study showed that high-fat and high-carbohydrate diet for 21 days proved to induce symptoms of MetS in rats. Symptoms of MetS observed in this study included a significant increase in weight gain, central obesity, blood glucose, TC, TG, LDL and decrease in HDL levels. When compared with the changes in the rat model of diabetes or obesity previously studied, some changes were similiar to those of the symptoms of MetS in humans. It was observed that on day 21 in the experimental groups after MetS induction, there were increased TC, TG, and LDL and decreased HDL levels compared to those of normal group. Interestingly, there was significant difference in TC, TG, LDL, and HDL among groups with MetS. The cause of the increase in TC, TG, LDL, and HDL decrease may be due to the induction of high-fat and high-carbohydrate diet. The results are consistent with that of previous studies, with high-fat and high-carbohydrate diet induction for 16 weeks of rat showing increase in weight, energy intake, abdominal fat deposition and abdominal circumference, impaired glucose tolerance, dyslipidemia, hyperinsulinemia, and increased leptin concentrations, and malondialdehyde plasma ${ }^{17}$. The results of several studies suggest that a diet high in carbohydrates, such as sucrose and 
fructose can induce hypertension, dyslipidemia, and impaired glucose tolerance, but failed to trigger central obesity. In contrast, high-fat and high-carbohydrate diet can induce central obesity and dyslipidemia. In fact, human diet causing MetS is much more complex than the high-fat diet alone $^{17}$. Thus the combination of high-fat and highcarbohydrate diet in rats are considered to be better to mimic the diet that causes MetS in humans ${ }^{17}$. In the present study high fructose and high in fat diet was used for induction of MetS. Previous research stated that high-fructose diet that mimic the diet in western countries is enough to produce obesity, insulin resistance, hyperglycemia, and hypertriglyceridemia leading to the development of MetS $^{18}$.

Porang glucomannan supplementation at a dose of 25, 50, and $100 \mathrm{mg} / 200 \mathrm{gBW}$ has been shown to improve blood lipid profiles in high-fat and high-carbohydrate diet induced metabolic syndrome rats indicated by lower TC, TG, and LDL, and higher levels of HDL in the group receiving porang glucomannan supplementation (GMP25, 50 , and $100 \mathrm{mg} / 200 \mathrm{~g} \mathrm{BW}$ ) for 28 days compared to that of SM group. These effects are correlated with an improvement in the symptoms of MetS due to dyslipidemia or hypertriglyceridemia. These finding supports those of previous a clinical studies using glucomannan from Amorphophallus konjac showing a significant lower total cholesterol, LDL cholesterol, and triglycerides, but not lower HDL cholesterol and blood pressure ${ }^{19}$. Konjac glucomannan supplementation for 4 weeks in patients wih type $2 \mathrm{DM}$ showed a lower cholesterol level ${ }^{20}$. A clinical study showed that intervention with konjac glucommanan at the dose of $3.9 \mathrm{~g}$ daily for 4 weeks significantly lower the total cholesterol level by $10 \%$, LDL by $7.2 \%$, and triglyceride by $23 \%$, and systolic blood pressure by $2.5 \%{ }^{21}$. In contrast, the administration of glucomannan noodles at $400 \mathrm{~g}$ for 4 weeks in with the MetS patients with diabetes risk factors showed no significant differences in lipid profiles. The noodle glucomannan only changed weight, BMI, waist circumference, hs-CRP, and glycated hemoglobin ${ }^{22}$. This present study showed porang glucomannan at the dose of $100 \mathrm{mg} / 200$ $\mathrm{gBW}$ is the most effective in reverse the symptoms of MetS (TC, TG, LDL, and HDL).

Glucomannan is the main and largest component of porang. Glucomannan has a fairly high viscosity, which is highly effective in the absorption of nutrients in the intestine. The higher concentration of the glucomannan porang, the higher viscosity it possess. Consumption of soluble fiber in the form of glucomannan will slow emptying of the intestine through the formation of gel with a high viscosity and large volumes that increase satiety effect and longer satiety ${ }^{23}$. Glucomannan is one example of "lente" carbohydrate that slowly absorbed. Slow absorption in GI tract lower LDL level and ApoB concentration $^{24}$. Glucomannan from porang acts as prebiotics $^{25}$. Glucomannan can be used as growth media of probiotics such as Bifidobacteria and Lactobacili $^{26}$. Prebiotic boost the bacterial growth 
of colonies in L-intestinal cells leading to the production of Short Chain Fatty Acid (SCFA) and thus Glucagon-Like Peptide 1 (GLP-1) produced ${ }^{27}$. GLP-1 increases the oxidation of Free Fatty Acid (FFA) and decreases FFA synthesis ${ }^{28}$. GLP-1 has a direct effect on the production of triglyceriderich lipoproteins in the liver and intestinal tract. Increased energy is due to the use of triglycerides in peripheral tissues and the activation of the central nervous system that regulates fat metabolism by GLP-1. Signals from GLP-1R decrease VLDL-TG production rates from the liver, reduce the contents of TG by modulating the major enzymes of lipid metabolism in the liver, interfere the lipogenesis of de novo hepatocytes and beta-oxidation. GLP-1 modulates reverse-cholesterol transport pathways, resulting in an increase in $\mathrm{HDL}^{29}$. In addition, GLP1 prevents the increment of intestinal chylomicron ${ }^{30}$. While central GLP-1 is thought as a novel regulator in producing chylomicron via melonocortin-4 receptors. Some of these mechanisms are thought to be able to lower TC, TG, and LDL level. The results of this study are expected to provide a strong scientific basis to encourage the use and development of glucomannan porang as a functional dietary ingredient for alternative prevention or treatment of MetS.

\section{Conclusion}

$$
\text { Porang glucomannan supplementation }
$$
(Amorphophallus muelleri Blume) at the doses of 25, 50, $100 \mathrm{mg} / 200 \mathrm{gBW}$ has been shown to improve the lipid profile (total cholesterol, triglycerides, LDL, and HDL) in animal model of metabolic syndrome. The dose of $100 \mathrm{mg} / 200 \mathrm{gBW}$ has been shown the most effective dose to lower total cholesterol, triglyceride, and LDL levels, and also increase HDL level. Further studies on the effect of porang supplementation on other parameters of the metabolic syndrome including weight, blood glucose levels, and blood pressure, and insulin resistance strongly associated with MetS are needed.

\section{Acknowledgment}

This research was supported by a grant from Indonesian Directorate General of Higher Education (DIKTI) in 2017 (No. 257/B.1/LPPMSA/VI/2017).

\section{Conflict of Interest}

The authors declares no conflict of interest regarding to this publication.

\section{References}

1. Alberti KGMM, Eckel RH, Grundy SM, Zimmet PZ, Cleeman JI, Donato KA, et al. Harmonizing the metabolic syndrome: A joint interim statement of the international diabetes federation task force on epidemiology and prevention; National heart, lung, and blood institute; American heart association; World heart federation; International atherosclerosis society; and International association for the study of obesity. Circulation. 2009; 120(16):1640-5. DOI: 10.1161/CIRCULATIONAHA.109.192644. Crossref. 
2. Alberti KG, Zimmet P, Shaw J. Metabolic SyndromeA new world-wide definition. A consensus statement from the international diabetes federation. Diabetic Medicine. 2006; 23(5):469-80. DOI: 10.1111/j.14645491.2006.01858.x. Crossref.

3. What is metabolic syndrome. American Heart Association; 2015. p. 1-2.

4. Aguilar M, Bhuket T, Torres S, Liu B, Wong RJ. Prevalence of the metabolic syndrome in the United States, 2003-2012. Jama. 2015; 313(19):1973-4. DOI: 10.1001/jama.2015.4260. Crossref.

5. Okafor C. The metabolic syndrome in Africa: Current trends. Indian J Endocrinol Metab. 2012; 16(1):56. DOI: 10.4103/2230-8210.91191. Crossref.

6. Balkau B, Charles MA, Drivsholm T, Wareham N, Yud- kin JS, Morris R, et al. Frequency of the WHO metabolic syndrome in European cohorts, and an alternative definition of an insulin resistance syndrome. Diabetes Metab. 2002; 28:364-76. DOI: DM-11-2002-28-5-1262-3636-101019-ART3.

7. Nestel P, Lyu Phd R, Huey W, Sheu -Hernig, Md WN, Saito I, et al. Metabolic syndrome: Recent prevalence in East and Southeast Asian populations. Asia Pac J Clin Nutr. 2007; 16(2):362-7.PMid:17468095

8. Goodarzi MT, Mohammadian M, Borzouei S, Hassanzadeh T. Association between Plasma cholesteryl ester transfer protein activity and lipid profiles in metabolic syndrome in an Iranian population. Int Res J Biol Sci. 2014; 3(4):2278-3202. ISSN: 2278-3202.

9. Kawamoto R, Tabara Y, Kohara K, Miki T, Kusunoki T, Takayama S, et al. Relationships between lipid profiles and metabolic syndrome, insulin resistance and serum high molecular adiponectin in Japanese community-dwelling adults. Lipids Health Dis. 2011; 10(1):79. Available from: http://www.lipidworld. com/content/10/1/79. Crossref. PMid:21586120 PMCid:PMC3118370
10. Balkau B, Charles MA. Comment on the provisional report from the WHO consultation. Diabet Med. 1999; 16(5):442-3. DOI: 10.1046/j.14645491.1999.00059.x. Crossref.

11. Galisteo M, Duarte J, Zarzuelo A. Effects of dietary fibers on disturbances clustered in the metabolic syndrome. J Nutr Biochem. 2008; 19(2):71-84. DOI: 10.1016/j.jnutbio.2007.02.009. Crossref.

12. Connolly ML, Lovegrove JA, Tuohy KM. Konjac Glucomannan hydrolysate beneficially modulates bacterial composition and activity within the faecal microbiota. J Funct Foods. 2010; 2(3):219-24. DOI: 10.1016/j.jff.2010.05.001.Crossref.

13. Safitri AH, Meryandini A. Enzymatic hydrolysis of porangbyStreptomycesviolascens BF 3.10 mannanase for the production of mannooligosaccharides. Med Pet. 2014; 37(3):190-7. DOI: 10.5398/ medpet.2014.37.3.190. Crossref.

14. Gallaher CM, Munion J, Hesslink R, Wise J, Gallaher DD. Cholesterol reduction by glucomannan and chitosan is mediated by changes in cholesterol absorption and bile acid and fat excretion in rats. Am J Clin Nutr. 2000; 130(11):2753-9.Crossref.

15. Jones PJH. Dietary agents that target gastrointestinal and hepatic handling of bile acids and cholesterol. J Clin Lipidol. 2008; 2(2):S4-10. DOI: 10.1016/j. jacl.2008.01.005. Crossref.

16. Koswara S. Teknologi pengolahan umbi-umbian bagian 2: Pengolahan umbi porang. bogor. Research and Community Service Institution IPB; 2013. Available from: http://seafast.ipb.ac.id

17. Panchal SK, Poudyal H, Iyer A, Nazer R, Alam MA, Diwan V, et al. High-carbohydrate, high-fat dietinduced metabolic syndrome and cardiovascular remodeling in rats: Erratum. J Cardiovasc Pharmacol. 2011; 57(5):610. DOI: 10.1097/ FJC.0b013e3181feb90a.Crossref. 
18. Sánchez I, Reynoso-Camacho R, Salgado LM. The diet-induced metabolic syndrome is accompanied by whole-genome epigenetic changes. Genes Nutr. 2015; 10(4):21. DOI: 10.1007/s12263-015-0471-5. Crossref.

19.Sood N,BakerWL, Coleman CI.Effect of glucomannan on plasma lipid and glucose concentrations, body weight, and blood pressure: Systematic review and meta-analysis. Am J Clin Nutr. 2008; 88(4):1167-75. PMid:18842808

20. Chen HL, Sheu WHH, Tai TS, Liaw YP, Chen YC. Konjac supplement alleviated hypercholesterolemia and hyperglycemia in type 2 diabetic subjects- A randomized double-blind trial. J Am Coll Nutr. 2003; 22(1):36-42.DOI: 10.1080/07315724.2003.10719273. Crossref.

21. Arvill A, Bodin L. Effect of short-term ingestion of konjac glucomannan on serum cholesterol in healthy men. Am J Clin Nutr. 1995; 61(3):585-9. Available from: http://www.ncbi.nlm.nih.gov/ pubmed/7872224. Crossref. PMid:7872224

22. Cheang KU, Chen CM, Chen CO, Liang FY, Shih CK, Li SC. Effects of glucomannan noodle on diabetes risk factors in patients with metabolic syndrome: A double-blinded, randomized crossover controlled trial. J Food Nutr Res. 2017; 5(8):622-8. DOI: 10.12691/jfnr-5-8-13.

23. Zalewski BM, Chmielewska A, Szajewska H. The effect of glucomannan on body weight in overweightoor obese children and adults: A systematic review of randomized controlled trials. Nutrition. 2015; 31:437-442.e2. DOI: 10.1016/j.nut.2014.09.004. Crossref.

24. Jenkins DJ, Jenkins AL, Wolever TM, Vuksan V, Rao A V, Thompson LU, et al. Low glycemic index:
Lente carbohydrates and physiological effects of altered food frequency. Am J Clin Nutr. 1994; 59(3 Suppl):706S-9S. Crossref. PMid:8116554

25. Yanuriati A, Marseno DW, Rochmadi, Harmayani E. Characteristics of glucomannan isolated from fresh tuber of porang (Amorphophallus Muelleri Blume). Carbohydr Polym. 2017; 156:56-63. DOI 10.1016/j. carbpol.2016.08.080. Crossref.

26. Al-Ghazzewi FH, Khanna S, Tester RF, Piggott J. The potential use of hydrolysed konjac glucomannan as a prebiotic. J Sci Food Agric. 2007; 87(9):1758-66. DOI: 10.1002/jsfa.2919. Crossref.

27. Alberti KGMM, Zimmet PZ. Definition, diagnosis and classification of diabetes mellitus and its complications part 1 : diagnosis and classification of diabetes mellitus provisional report of a WHO consultation. Diabet Med. 1998; 15(7):539-53. Crossref.

28. Mccarty MF, Dinicolantonio JJ. Prebiotics promote metabolic health and longevity by stimulating intestinal production of GLP-1. Open Heart. 2015; 2(1):e000205. DOI: 10.1136/openhrt-2014-000205. Crossref.

29. Patel VJ, Joharapurkar AA, Shah GB JM. Effect of GLP-1 based therapies on diabetic dyslipidemia. Curr Diabetes Rev. 2014; 10(4):238-50. Available from: https://www.ncbi.nlm.nih.gov/pubmed/24998439. Crossref. PMid:24998439

30. Farr S, Taher J, Adeli K. Glucagon-like peptide-1 as a key regulator of lipid and lipoprotein metabolism in fasting and postprandial states. Cardiovascular and Haematological Disorders-Drug Targets (Formerly Current Drug Targets-Cardiovascular and Hematological Disorders). 2014; 14(2):126-36. Crossref. 